"What are you doing, sir?" inquired Gov. Eastman. "Calling the joint roll!" replied the clerk. "What for?" asked the Governor. "To learn whether a quorum is present," said the clerk. "Well, sir, you needn't do it; 't'aint in the law!" And he pointed to the section of the Code under which the body was acting. It may be presumed that after that the clerk waited for the Governor's orders before attempting to proceed with business.

Up to near the close of President Buchanan's administration Mr. Eastman was an old-school democrat. Not long before he left the party, he made a democratic speech in the old town hall at Webster City, an edifice which disappeared from the face of the earth more than 30 years ago. The speaker could not keep back a joke, even when it hit bimself or his party. At that time-just before the civil war-the republicans claimed that the United States Treasury had been bankrupted by the Buchanan administration, and much was said in the papers on that topic. But Mr. Eastman boasted that the democracy had "governed the country for forty years," "whipped Mexico," and "given the nation the Sub-Treasury system," as it then existed. He stopped an instant and looking around, remarked, "But, by the way, our republican friends say there is nothing in the Treasury." This "brought down the house," and he laughed as heartily as his most pronounced opponent in the audience.

But when the great civil war burst upon the country, Gov. Eastman loyally supported the Union cause, finding himself thenceforth in accord with the party of Abraham Lincoln. The story of his career is well told by his life-long friend, Hon. W. J. Moir.

\title{
AN IOWA MATHEMATICIAN AND HIS WORK.
}

Few people are aware that a bi-monthly magazine of "Pure and Applied Mathematics" was published in the city of Des Moines for a period of ten years. Its title was The 
Analyst. The first number was issued in January, 1874, and the last in November, 1883. The office which was the home of the editor was three blocks east and one block south of the capitol. Each number of this magazine contained 16 and each volume about 200 pages. As a literary work it occupied quite a unique and anomalous position. Its modest circulation was confined to mathematicians and astronomers, for the most part in colleges. When the publication was first announced some of these good people entertained such grave doubts of its success that they withheld their subscriptions. In one instance an eminent gentleman who has since taken his place among those whom the world deems illustrious, wrote Dr. Hendricks, the editor and publisher, a somewhat testy letter rating him on account of his presumption, though a few years later he was glad to procure every number of The Analyst. The publication went to a small and select constituency which was scattered throughout the world. Dr. Hendricks thus came into pleasant relations with men profoundly learned in most civilized countries. The type for the pages of the little magazine was set by his daughters, in his own house, from fonts of type which he had procured for this purpose. The printing was done at one of the offices in the city of Des Moines.

Dr. Hendricks was a self-educated man whose school advantages had been very limited, but he had a natural aptitude for the study of mathematics in which he became thoroughly learned. He settled in Des Moines in 1864. The first ten years of his residence in the capital city he was mainly engaged in surveying, having previously carried out a large contract under the surveyor-general of Colorado. The succeeding ten years-1874 to 1883 -were devoted to the publication of The Analyst. In the latter year, clearly discerning that the disabilities and limitations of age were creeping upon him, Dr. Hendricks determined to discontinue its publication. This step met with the sincere regret of math. ematicians in all parts of the world, but it was inevitable, for 
there was no one to take his place as its editor. He had prepared an index for each volume at its close; but when he decided to discontinue the work he announced this fact to his readers and compiled and printed a general index to the ten volumes, thus systematically rounding out and completing his labors. He presented a set of The Analyst to the Historical Department, with many original letters from his correspondence. These letters were inserted in the bound volumes thus making an important addition to the data for his biography. Mr. John J. Hamilton, of The Des Moines Daily News, wrote a full and highly interesting sketch of the life of Dr. Hendricks, which was published with his portrait; and Prof. Florian Cajori, of the University of Wisconsin, under the auspices of the United States Bureau of Education, Washington, D. C., published a paper on "Mathematical Journals," in which he paid a high tribute to "Joel E. Hendricks, a self-taught mathematician." Among other matters Dr. Hendricks wrote his autobiography, the original manuscript of which was also bound with Vol. I of The Analyst. These biographical materials, thus incorporated with his work, form a unique, but tasteful and most appropriate memorial of this quiet and devoted Des Moines scholar. He died June 8, 1893, at the age of 75 years.

\section{OUR TLLUSTRATIONS.}

Our frontispiece is an original steel engraving of the portrait of the lamented Philip M. Crapo. We did not receive the impressions from the plate in time to have them appear with the announcement of his death, and we therefore present them in the present issue of The Annals. This portrait is deemed by his friends to be one of rare excellence -a triumph of the engravers' art. It affords us great pleasure to present it in our pages.

Our portrait of the late Honorable Enoch W. Eastman 
Copyright of Annals of Iowa is the property of State of Iowa, by \& through the State Historical Society of Iowa and its content may not be copied or emailed to multiple sites or posted to a listserv without the copyright holder's express written permission. However, users may print, download, or email articles for individual use. 